\title{
Influence of Bainite Fraction on Improving Mechanical Properties of Quenched and Tempe- red High Silicon Steel
}

Kateřina Opatová, Ivan Vorel, Štepán Jeníček, Michal Peković

University of West Bohemia, Regional Technological Institute, Univerzitní 22, Plzeň, Czech Republic

E-mail: opatovak@rti.zcu.cz, frost@rti.zcu.cz,jeniceks@rti.zcu.cz,pekovicm@rti.zcu.cz

Martensitic steels are characterized by high strength which, on the other hand, is offset by considerable brittleness. This drawback can be partly corrected by tempering, at the cost of reduced final strength. If steel is alloyed with a sufficient amount of silicon, an optimum heat treatment sequence can produce a mixed microstructure consisting of martensite and carbide-free bainite. In various microstructures of this composition with identical grain size, mechanical properties would be dictated predominantly by the fraction of bainite. This article deals with designing a heat treatment sequence for a low-alloy steel. It is part of a research into the impact of bainite fraction on mechanical properties of materials with martensitic-bainitic microstructure. At an appropriate ratio of martensite and bainite, a steel with $0.42 \% \mathrm{C}$ can exhibit strengths above $2200 \mathrm{MPa}$ at A5mm elongation of more than $17 \%$.

Keywords: Bainite, martensite, silicon, mechanical properties

\section{Introduction}

Bainitic transformation in steel can take place isothermally or during continuous cooling. In ordinary steels with low levels of silicon, this transformation is accompanied by cementite precipitation from the newly-formed bainite laths. Depending on temperature, cementite particles precipitate either along bainite laths, which occurs in the case of upper bainite, or within the bainite laths, such as in lower bainite. At higher silicon levels, cementite formation during bainitic transformation is suppressed by the low solubility of silicon in cementite $[1,2,3]$. Consequently, carbon migrates from super-saturated bainite laths to the surrounding austenite, and stabilises it. The result is a microstructure of bainitic ferrite laths separated by carbon-enriched austenite films $[4,5,6]$.

In steels with a high silicon content, the abovedescribed effect of silicon causes the bainite reaction to stop before the equilibrium state is reached. The extent of bainitic transformation depends on the temperature of isothermal annealing. During isothermal annealing, the bainite reaction apparently stops before all austenite is transformed to bainitic ferrite, i.e. after a certain bainite fraction has formed. By means of extensive calculations of thermal and mechanical variables of the austenite-bainite transformation during isothermal annealing, the shape of the Bstop curve can be determined, depending on the isothermal annealing temperature. The Bstop curve indicates the limit concentration of carbon in austenite, at which bainite reaction can still continue (Fig. 1) [5, 7, 8].

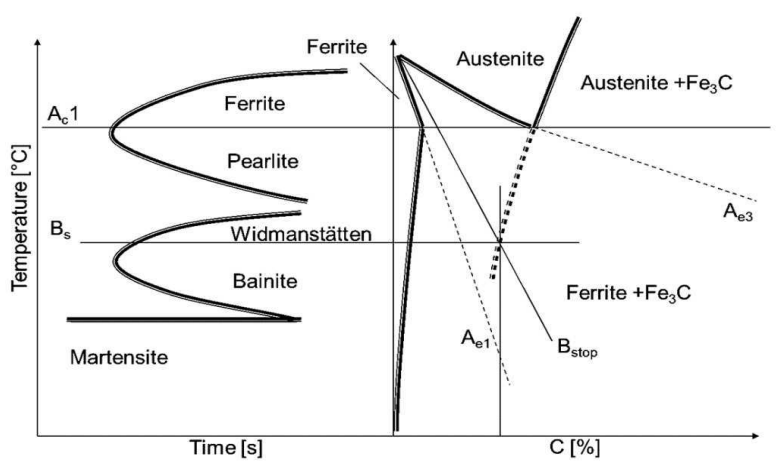

Fig. 1 Schematic illustration of principles of the Bstop curve, the bainite reaction stop curve, for isothermal annealing of high-silicon steel

\section{Experimental programme}

The purpose of this experimental programme was to design a heat treatment sequence that produces martensitic-bainitic microstructure to provide a combination of the high strength of martensite and the excellent ductility of cementite-free bainite $[9,10]$. For this experiment, a lowalloy silicon steel was chosen (Tab. 1). In its basic condition, it has a ferrite-pearlite microstructure and an ultimate strength of $981 \mathrm{MPa}$ and elongation of $30 \%$.

Tab. 1 Chemical composition of experimental steel

\begin{tabular}{|c|c|c|c|c|c|c|c|c|c|}
\hline $\mathbf{C}$ & $\mathbf{S i}$ & $\mathbf{M n}$ & $\mathbf{C r}$ & $\mathbf{M o}$ & $\mathbf{N b}$ & $\mathbf{P}$ & $\mathbf{S}$ & $\mathbf{M s}\left[{ }^{\circ} \mathbf{C}\right]$ & $\mathbf{M f}\left[{ }^{\circ} \mathbf{C}\right]$ \\
\hline 0.42 & 2.03 & 2.5 & 1.33 & 0.16 & 0.03 & 0.005 & 0.003 & 199 & 67 \\
\hline
\end{tabular}

The first phase of the experiment involved heat treatment of specimens of the experimental steel: heating to an austenitizing temperature of $900{ }^{\circ} \mathrm{C}$ and soaking for 180 seconds, followed by quenching to ambient temperature. The specimens were then tempered at various temperatures: $150,175,200$, and $300^{\circ} \mathrm{C}$, each time for 600 seconds. Test pieces for tension testing were manufactured from these specimens. Mechanical properties after these separate schedules were determined by tension testing.

At the next phase, computations were carried out to determine the Bstop curve for the steel and the phase fractions after schedules with various temperatures, at which quenching is interrupted in the region of bainitic transformation (Fig. 2, 3). 


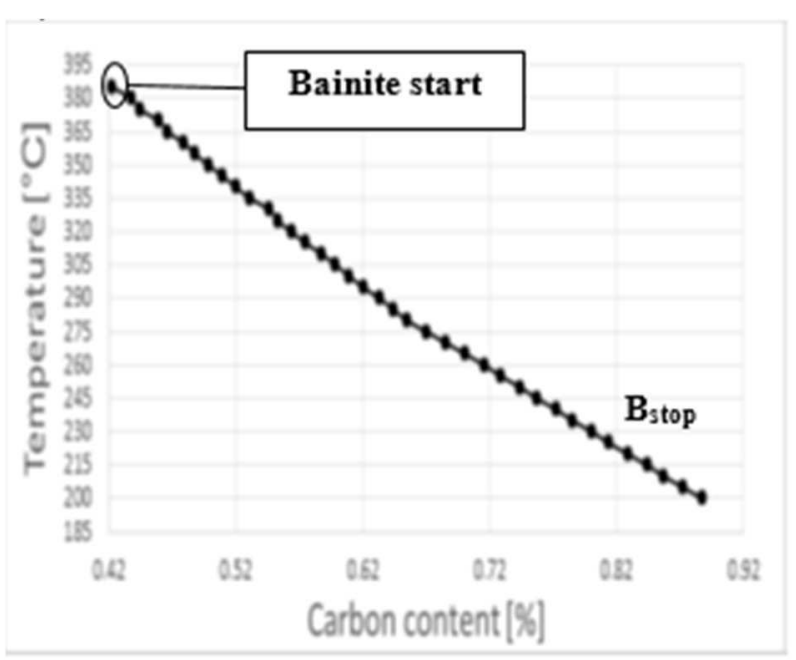

Fig. 2 Bainite reaction stop curve for isothermal annealing $B_{\text {stop }}$

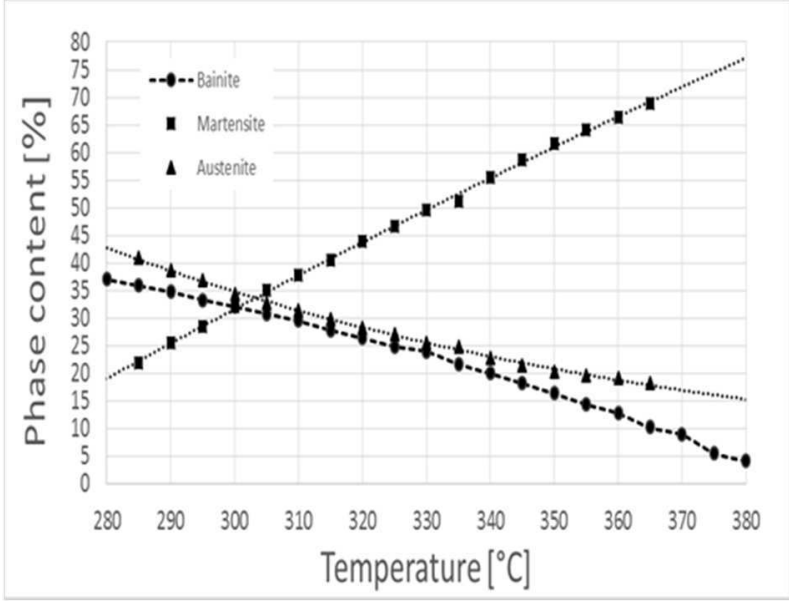

Fig. 3 Calculated phase fractions for schedules with various temperatures, at which quenching was interrupted in the region of bainitic transformation, and subsequently resumed

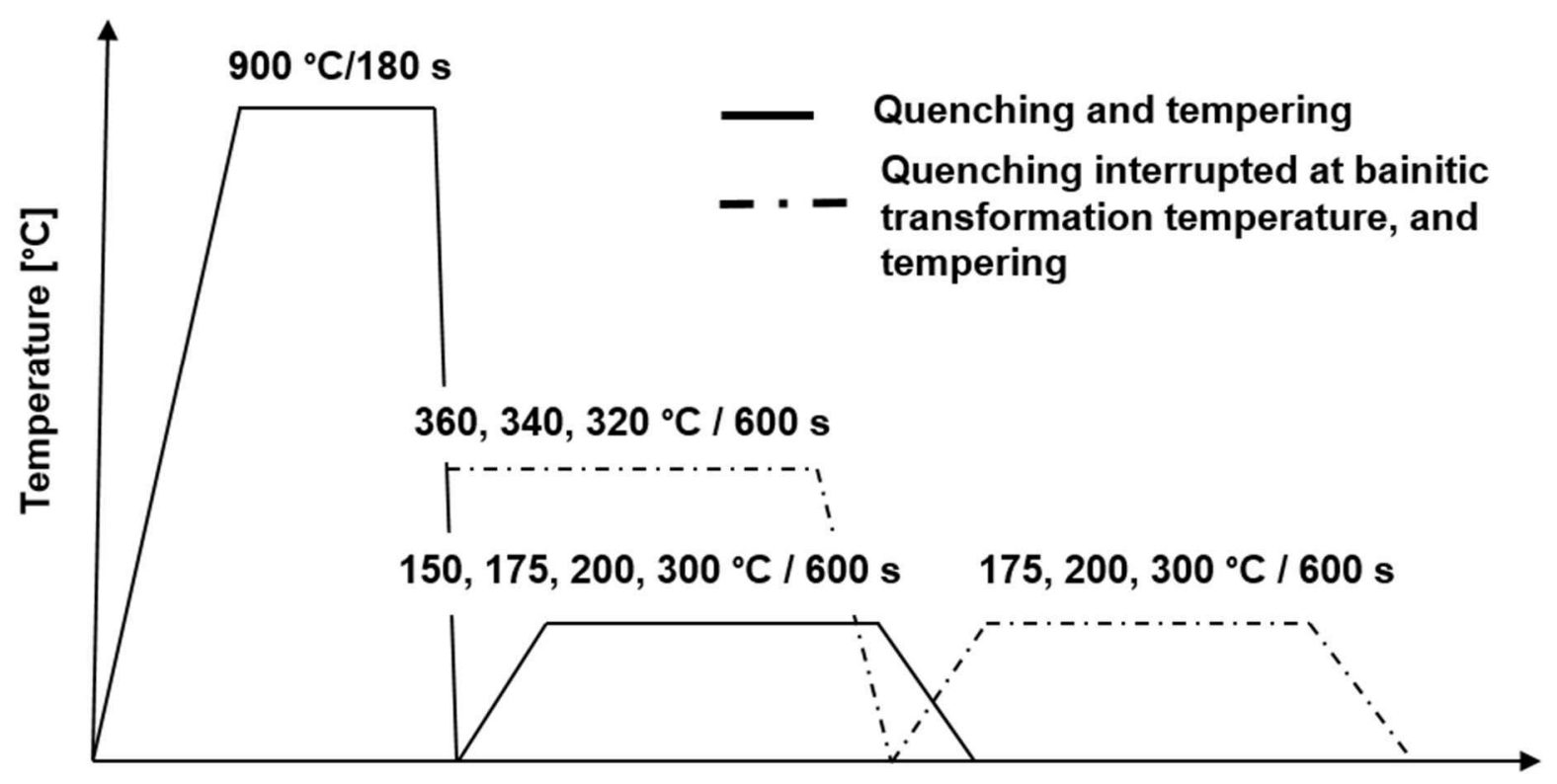

Fig. 4 Schematic illustration of heat treatment sequences for the experimental steel

Using this data, new heat treatment sequences were designed. They comprised austenitizing at $900^{\circ} \mathrm{C}$ for 180 seconds, quenching to one of the bainitic transformation temperatures of 360,340 , and $320^{\circ} \mathrm{C}$, holding for 600 seconds, and resumed quenching to ambient temperature. The final stage of the heat treatment sequence involved tempering at one of the temperatures of 175, 200, and 300 ${ }^{\circ} \mathrm{C}$ for 600 seconds (Fig. 4).

\section{Results and discussion}

Tension test pieces and specimens for metallographic examination were made from the heat-treated specimens. The gauge length of the test pieces was $5 \mathrm{~mm}$, and the dimensions of their cross-section at the measured point were $2 \times 1.5 \mathrm{~mm}$. For each heat treatment sequence, 3 representative test pieces were produced. Mean values were calculated from their mechanical properties data.

\subsection{Mechanical Properties}

The first tests conducted were tension tests on specimens from the quenched and tempered material. The highest strength was found in quenched and untempered specimens: ultimate strength in excess of $2300 \mathrm{MPa}$ and elongation of approximately $2 \%$ (Fig. 5). Tempering led to improved elongation and to lower ultimate strengths. The lowest strength, $1850 \mathrm{MPa}$, was found in the specimens tempered at $300{ }^{\circ} \mathrm{C}$. The A5mm elongation was 9 \% (Fig. 6). 


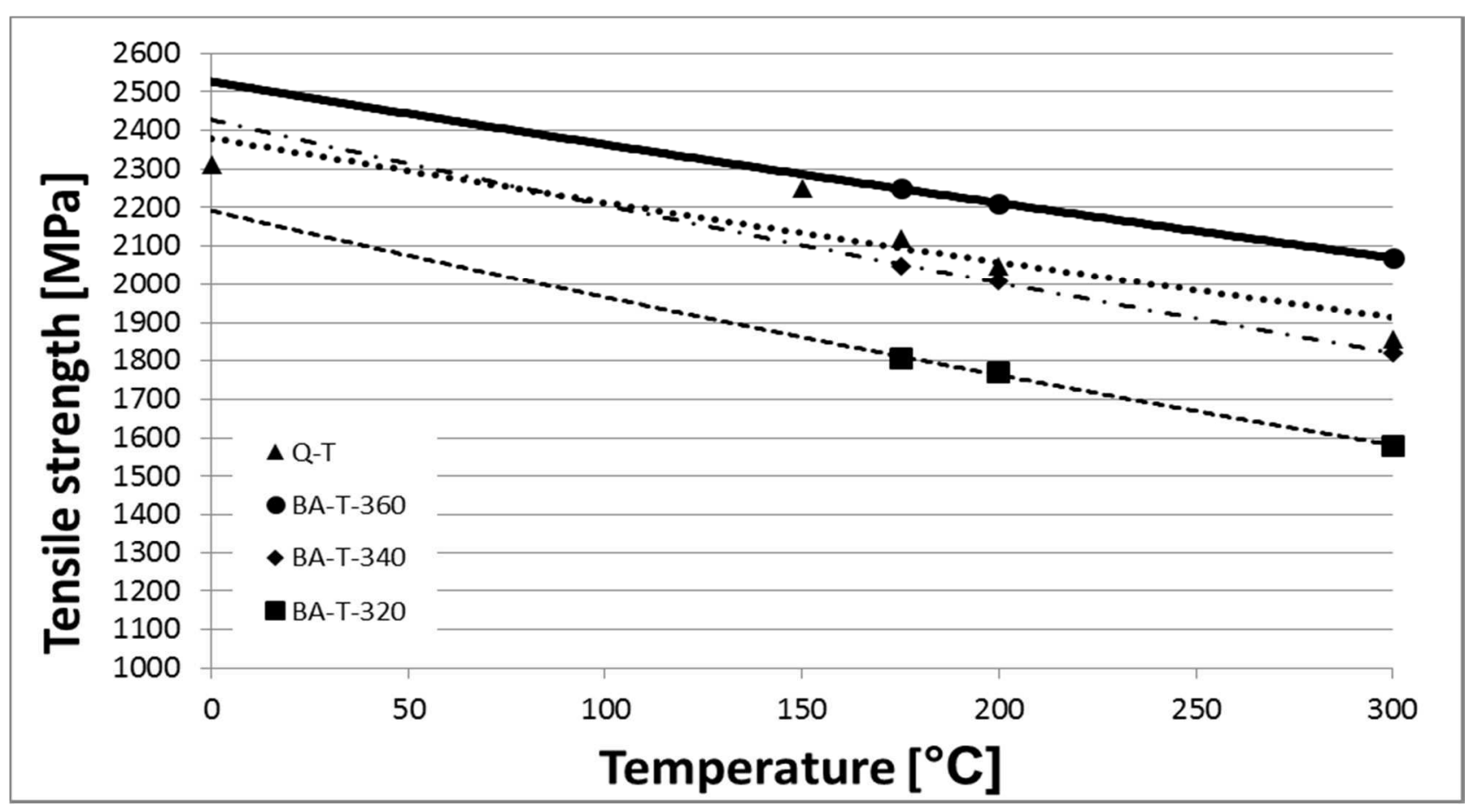

Fig. 5 Ultimate strength of the experimental steel after quenching and tempering - Q-T (tempering time: 600 s); and after quenching interrupted at the bainitic transformation temperature, and tempering - BA-T (isothermal holding time: $600 \mathrm{~s}$, tempering time: $600 \mathrm{~s}$ )

Mechanical properties of specimens after quenching interrupted at the bainitic transformation temperature and tempering were remarkable (Fig. 5, 6). The lowest strengths were found in the specimens whose quenching was interrupted at $320{ }^{\circ} \mathrm{C}$. The strengths of those specimens whose quenching was interrupted at $340{ }^{\circ} \mathrm{C}$ were comparable to the quenched and tempered specimens. In those specimens whose quenching was interrupted at $360{ }^{\circ} \mathrm{C}$, the strength level was approx. $200 \mathrm{MPa}$ lower than in the quenched and tempered specimens. The highest A5mm elongation was found in the specimens whose quenching was interrupted at $360^{\circ} \mathrm{C}$. Depending on their tempering temperature, it was between 14 and $17 \%$. In the specimens whose quenching was interrupted at 320 and 340 ${ }^{\circ} \mathrm{C}$, the A5mm elongation levels were comparable: $10-14$ $\%$, depending on the tempering temperature. The smallest elongation was found in the quenched and tempered specimens: $2-9 \%$, depending on the tempering temperature.

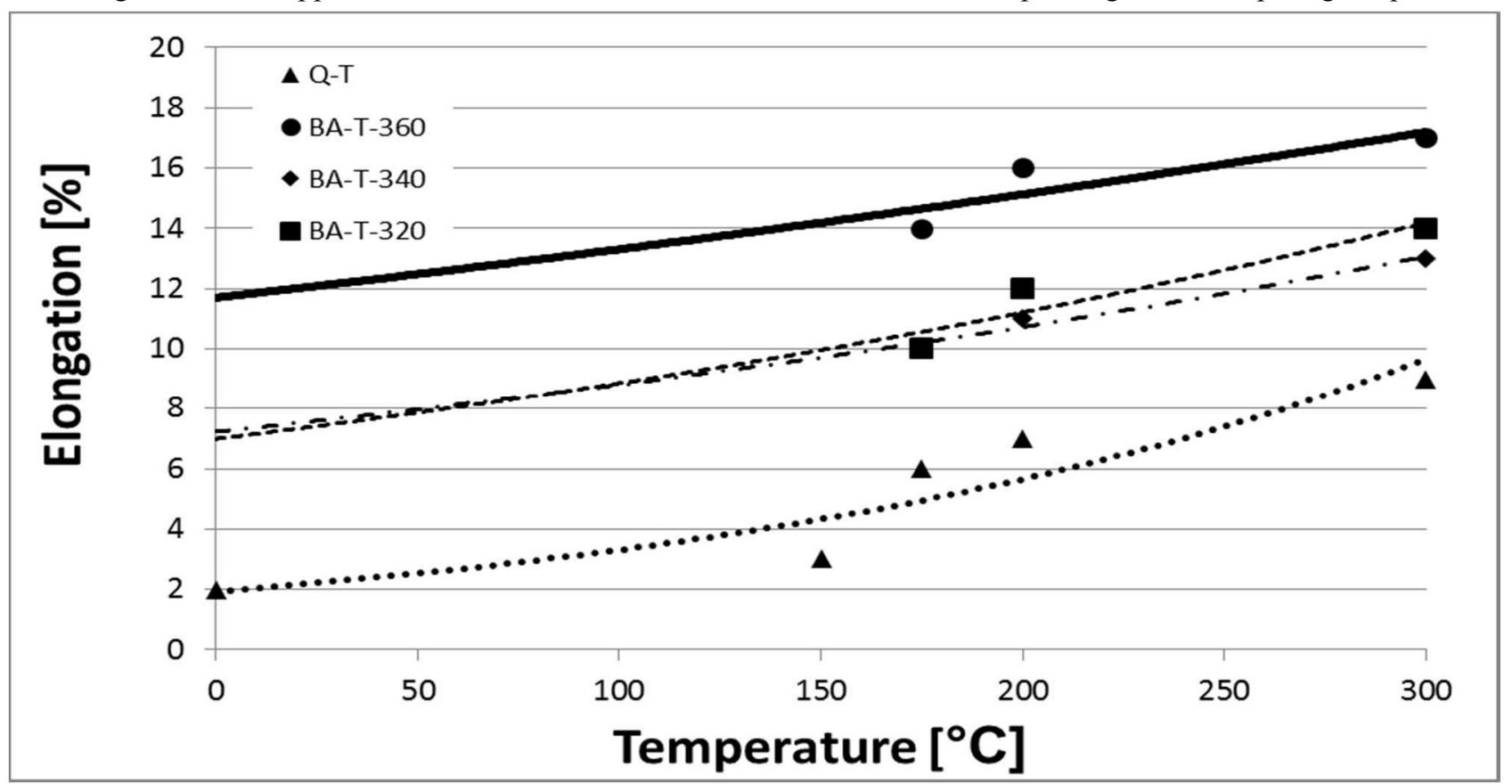

Fig. 6 Elongation (A5mm) of the experimental steel after quenching and tempering - Q-T (tempering time: $600 \mathrm{~s}$ ); and after quenching interrupted at the bainitic transformation temperature and tempering - BA-T (isothermal holding time: 


\subsection{Metallographic characterization}

Microstructures of the specimens were examined using optical and scanning electron microscopy. They were revealed by etching with $4 \%$ picric acid, $1 \% \mathrm{HCl}$, and $3 \%$ nital. Using image analysis, phase compositions were determined. The results were compared with the outcomes of thermodynamic calculations.

Microstructures of the specimens whose quenching was interrupted at the bainitic transformation temperature consisted of a mixture of martensite and bainite (Fig. 7). Their ratio varied with the temperature at which quenching was interrupted. In the specimen whose quenching was interrupted at $360{ }^{\circ} \mathrm{C}$, image analysis revealed $10 \%$ bainite. In the specimen with the quench interruption temperature of $340{ }^{\circ} \mathrm{C}$, there was $21 \%$ bainite, and in the specimen whose quenching was interrupted at $320^{\circ} \mathrm{C}$, the amount of bainite was $28 \%$. These values were in very good agreement with the calculated values (Tab. 2).
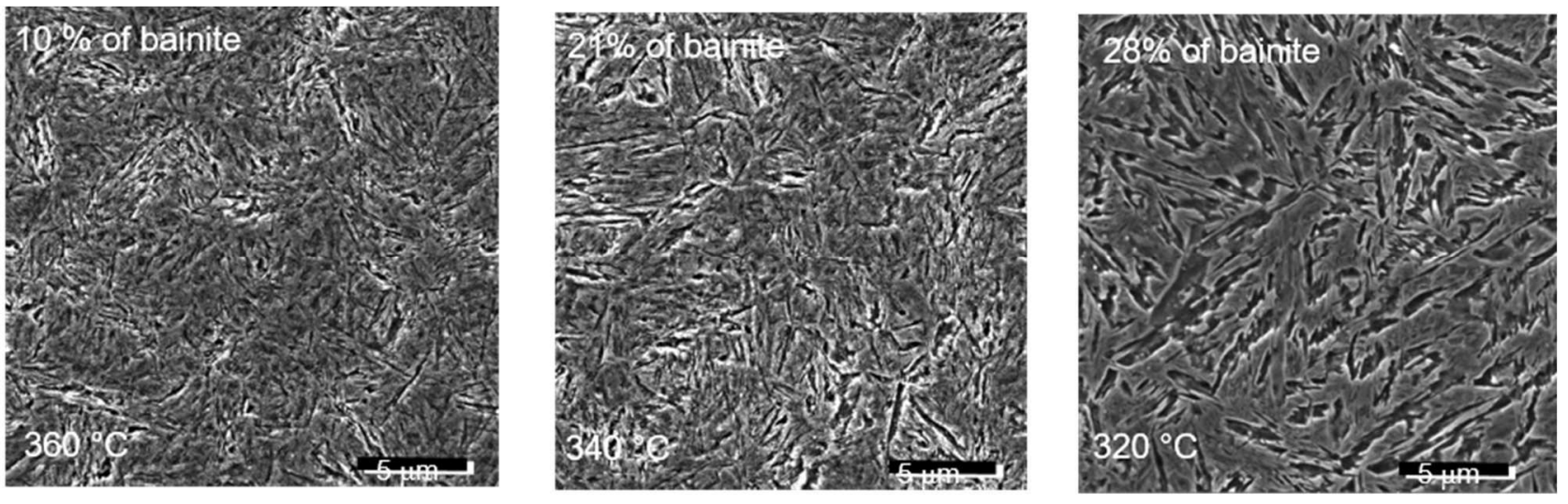

Fig. 7 Micrographs of specimens after quenching which was interrupted at the bainitic transformation temperatures of 320,340 , and $360^{\circ} \mathrm{C}$ for $600 \mathrm{~s}$, then continued, and followed by tempering at $300{ }^{\circ} \mathrm{C}$ for $600 \mathrm{~s}$

Martensite could not be distinguished from retained austenite using either scanning electron microscope or optical microscope. Therefore, their amounts were determined as complements to $100 \%$ using the levels of phases found by image analysis. Microstructure observation did not confirm any significant effect of the tempering temperature on the resulting microstructure.

Tab. 2 Measured and calculated bainite and martensite fractions in specimens after quenching interrupted at bainitic transformation temperatures of 320,340 , and $360^{\circ} \mathrm{C}$, and subsequent tempering

\begin{tabular}{|c|c|c|c|}
\hline & Bainite [\%] & \multicolumn{2}{|c|}{ Martensite [\%] + retained austenite[\%] } \\
\hline Experimental measurement BA-T $-360^{\circ} \mathrm{C}$ & 10 & \multicolumn{2}{|c|}{90} \\
\hline Experimental measurement BA-T- $340^{\circ} \mathrm{C}$ & 21 & \multicolumn{2}{|c|}{79} \\
\hline Experimental measurement BA-T- $320^{\circ} \mathrm{C}$ & 28 & \multicolumn{2}{|c|}{72} \\
\hline Theoretical calculation BA-T- $360^{\circ} \mathrm{C}$ & 13 & 69 & 18 \\
\hline Theoretical calculation BA-T- $340^{\circ} \mathrm{C}$ & 20 & 59 & 21 \\
\hline Theoretical calculation BA-T- $320^{\circ} \mathrm{C}$ & 26 & 46 & 28 \\
\hline
\end{tabular}

\section{Conclusion}

This study explored the potential for achieving better mechanical properties in a steel containing $0.43 \% \mathrm{C}, 2.01$ $\% \mathrm{Si}, 2.5 \% \mathrm{Mn}$, and $1.33 \% \mathrm{Cr}$ by producing a microstructure of martensite and bainite. To this end, a heat treatment sequence was designed which comprised a quenching operation which was interrupted at the bainitic transformation temperature, then continued and completed, and followed by tempering. It was based on the finding that isothermal bainitic transformation is incomplete when there is a high level of silicon in the steel. Using thermodynamic calculations, a heat treatment sequence was designed for such a steel. The interruption temperature was the bainite stop temperature, Bstop. The fractions of phases after heat treatment were calculated for various bainitic transformation temperatures. These values were compared with the outcomes of image analysis. Mechanical properties of specimens treated according to the schedules with quenching interrupted at the bainitic transformation temperature and subsequent tempering were compared with those of specimens after plain quenching and tempering.

The quenched and untempered steel showed a strength of approx. $2300 \mathrm{MPa}$ and $\mathrm{A} 5 \mathrm{~mm}$ elongation of $2 \%$. After tempering at $150{ }^{\circ} \mathrm{C}$ for 600 seconds, the strength decreased to $2250 \mathrm{MPa}$ and the $\mathrm{A} 5 \mathrm{~mm}$ elongation reached $3 \%$. After tempering at $175{ }^{\circ} \mathrm{C}$, the steel exhibited a strength of $2100 \mathrm{MPa}$ combined with $\mathrm{A} 5 \mathrm{~mm}$ elongation of $6 \%$. After tempering at $200{ }^{\circ} \mathrm{C}$, the steel had a strength of $2032 \mathrm{MPa}$ and $\mathrm{A} 5 \mathrm{~mm}$ elongation of $7 \%$. The lowest strength was obtained by tempering at $300{ }^{\circ} \mathrm{C}: 1850 \mathrm{MPa}$. In this case, A5mm elongation was $9 \%$.

In specimens whose quenching was interrupted at the bainitic transformation temperature of $320^{\circ} \mathrm{C}$ for $600 \mathrm{se}-$ conds, then continued and followed by tempering for 600 seconds, the ultimate strength was $1560 \mathrm{MPa}$ upon tempering at $175^{\circ} \mathrm{C}, 1770 \mathrm{MPa}$ upon $200{ }^{\circ} \mathrm{C}$, and $1810 \mathrm{MPa}$ 
after tempering at $300{ }^{\circ} \mathrm{C}$. After tempering at $175^{\circ} \mathrm{C}$, the A5mm elongation was $10 \%$, whereas after $200{ }^{\circ} \mathrm{C}$ it was $12 \%$, and upon $300{ }^{\circ} \mathrm{C}$, the $\mathrm{A} 5 \mathrm{~mm}$ value was $14 \%$. The microstructure contained $28 \%$ bainite.

In specimens whose quenching was interrupted at the bainitic transformation temperature of $340^{\circ} \mathrm{C}$ for 600 seconds, then continued and followed by tempering for 600 seconds, the ultimate strength was $2050 \mathrm{MPa}$ upon tempering at $175^{\circ} \mathrm{C}, 2010 \mathrm{MPa}$ upon $200{ }^{\circ} \mathrm{C}$, and $1820 \mathrm{MPa}$ after tempering at $300{ }^{\circ} \mathrm{C}$. After tempering at $175^{\circ} \mathrm{C}$, the A $5 \mathrm{~mm}$ elongation was $10 \%$, whereas after $200{ }^{\circ} \mathrm{C}$ it was $11 \%$, and upon $300{ }^{\circ} \mathrm{C}$, the $\mathrm{A} 5 \mathrm{~mm}$ value was $13 \%$. The microstructure contained $21 \%$ bainite.

In specimens whose quenching was interrupted at the bainitic transformation temperature of $360^{\circ} \mathrm{C}$ for $600 \mathrm{se}-$ conds, then continued and followed by tempering for 600 seconds, the ultimate strength was $2240 \mathrm{MPa}$ upon tempering at $175^{\circ} \mathrm{C}, 2200 \mathrm{MPa}$ upon $200{ }^{\circ} \mathrm{C}$, and $2070 \mathrm{MPa}$ after tempering at $300{ }^{\circ} \mathrm{C}$. After tempering at $175^{\circ} \mathrm{C}$, the A $5 \mathrm{~mm}$ elongation was $14 \%$, whereas after $200^{\circ} \mathrm{C}$ it was $16 \%$, and upon $300{ }^{\circ} \mathrm{C}$, the $\mathrm{A} 5 \mathrm{~mm}$ value was $17 \%$. The microstructure contained $10 \%$ bainite.

The comparison between bainite fractions determined by measurement in specimens whose quenching was interrupted at the bainitic transformation temperature and the values found by theoretical calculates showed that there was very good agreement.

\section{Acknowledgements}

This paper includes results achieved within the project LO1502 Development of Regional Technological Institute. The project is subsidised by the Ministry of Education of the Czech Republic from specific resources of the state budget for research and development.

\section{References}

[1] BHADESHIA, H., EDMONDS, D. (1983). Bainite in silicon steels. In: new composition-property approach Part 1. Met. Sci., Vol. 17, pp. 411-419

[2] SUGimoto, K., IIDA, T., SAKAGUCHI, J., KASHIMA, T. (2000). Retained austenite characteristics and tensile properties in a TRIP type bainitic sheet steel. In: ISIJ Int., Vol. 40, pp. 902-908
[3] SAKUMA, Y., MATSUMURA, O., AKISUE, O. (1991). Inuence of $C$ content and annealing temperature on microstructure and mechanical properties of $400{ }^{\circ} \mathrm{C}$ transformed steel containing retained austenite. In: ISIJ Int., Vol. 31, pp. 1348-1353

[4] HANZAKI, A., HODGSON, P., YUE, S. (1997). Retained austenite characteristics in thermodynamically processed $\mathrm{Si}-\mathrm{Mn}$ transformationinduced plasticity steels. In: Metall. Mater. Trans. A, Vol. 28 , pp. $2405-2414$

[5] BHADESHIA, H., EDMONDS, V. (1980). The mechanism of bainite formation in steels. In: Acta Metall., Vol. 28, pp. 1265-1273

[6] PEKOVIĆ, M. VORL, I., KÁŇA, J., OPATOVÁ, K. (2017) Evolution of Microstructure and Mechanical Properties in Steels during Isothermal Holding in the Region of Bainitic Transformation Temperature in Dependence on Silicon Content. In: Manufacturing Technology, Vol. 17, pp. 549555

[7] JACQUES, P. (2003). Experimental investigation of the inuence of the austenite grain size on the mechanism and kinetics of the bainite transformation in steels. In: J. Phys. IV., Vol. 112, pp. 297300

[8] TSUKATANI, I., HASHIMOTO, S., INOUE, T. (1991). Effect of silicon and manganese addition on mechanical properties of high-strength hotrolled sheet steel containing retained austenite. In: ISIJ Int., Vol. 31, pp. 992-1000

[9] JENÍČEK, Š., VOREL, I., KÁŇA, J., OPATOVÁ, K. (2017). The use of material-technological modelling to determine the effect of temperature and amount of deformation on microstructure evolution in a closed-die forging treated by controlled cooling. In: Manufacturing Technology, Vol. 17, pp. 326-330

[10] BUBLÍKOVÁ, D.,JENÍČEK, Š.,KÁŇA, J.,VOREL, I. (2018) Effects of Cooling Rate in an Innovative Heat Treatment Route for High- Strength Steels. In: Manufacturing Technology, Vol. 18 , pp. $16-21$ 